\title{
PERAN VITAMIN C TERHADAP PIGMENTASI KULIT
}

\author{
Melisa V. Kembuan \\ Sunny Wangko \\ George N. Tanudjaja
}

\author{
Bagian Anatomi-Histologi Fakultas Kedokteran Universitas Sam Ratulangi Manado \\ Email: veronicamelisa@rocketmail.com
}

\begin{abstract}
The effective use of vitamine $\mathrm{C}$ for skin care has been widely recognized, in particular its use to make the skin more radiant. This is related to the action of vitamine $\mathrm{C}$ as a powerful antioxidant which can be easily absorbed by the body. Several clinical trials found that vitamine $\mathrm{C}$ had a positive effect as a skin pigmentation lightener. Some treatment for pigment disorders, in this case the management of melasma and senile lentigos, includes vitamine $\mathrm{C}$ as a systemic treatment.
\end{abstract}

Key words: vitamin C, pigmentation, melanocyte.

\begin{abstract}
Abstrak: Efek vitamin C untuk kecantikan kulit telah banyak diterapkan, khususnya penggunaan vitamin $C$ untuk efek pencerahan kulit. Hal ini berkaitan dengan sifat vitamin C yang merupakan antioksidan kuat dan dapat diserap mudah oleh tubuh. Dari beberapa pengujian klinis ditemukan bahwa efek vitamin C terhadap pigmentasi mempunyai hasil positif yaitu dapat mencerahkan kulit. Beberapa pengobatan untuk masalah kelainan pigmen dalam hal ini penatalaksanaan melasma dan lentigo senilis menggunakan vitamin $\mathrm{C}$ untuk pengobatan sistemik.
\end{abstract}

Kata kunci: vitamin C, pigmentasi, melanosit.

Kulit merupakan organ yang esensial dan vital serta merupakan cermin kesehatan dan kehidupan. ${ }^{1}$ Kulit memiliki fungsi yang sangat penting untuk perlindungan organ tubuh bagian dalam terhadap berbagai rangsangan dari luar, baik rangsangan mekanis, kimia, maupun radiasi. Paparan sinar ultra violet terhadap kulit merupakan contoh rangsangan radiasi yang dapat mempengaruhi warna kulit, bila berlebih akan muncul bercak-bercak coklat kehitaman, kering, dan warna kulit tidak merata. ${ }^{2}$

Sebagian besar orang Indonesia memiliki warna kulit coklat atau sawo matang. Orang yang mempunyai kulit coklat menganggap bahwa warna kulit yang terang dan bersih ialah kulit yang cantik. Demikian pula orang Indonesia, khususnya wanita menganggap bahwa kulit terang tanpa bercak-bercak hitam ialah kulit yang cantik. Hal ini membuat orang berupaya untuk membuat warna kulit mereka kembali seperti sedia kala, atau mereka ingin menaikkan tingkat warna kulit mereka. Sebagian besar masyarakat Indonesia ingin memiliki kulit yang lebih putih dengan menggunakan berbagai macam pemutih kulit baik topikal maupun sistemik.

Ditinjau dari aspek kosmetik, lesi hiperpigmentasi merupakan kondisi yang tersering dikeluhkan. Reaksi inflamasi penyerta juga sering ditemukan akibat pemakaian berbagai bahan peeling kimiawi, terapi laser, dan berbagai obat topikal. ${ }^{3 .}$

Kameyama et al (1990) melakukan penelitian dan menemukan bahwa vitamin C merupakan salah satu antioksidan yang dapat membantu mencerahkan warna kulit, sehingga vitamin $\mathrm{C}$ telah digunakan sebagai terapi untuk masalah pada warna kulit 
gelap dan bermasalah. ${ }^{4}$ Dalam waktu terakhir ini maraknya penggunaan vitamin $\mathrm{C}$ secara infus (intravena) yang diyakini dengan cara demikian dengan cepat warna kulit akan terlihat lebih cerah dan sehat dari sebelumnya, vitamin $\mathrm{C}$ sebagai bahan utama pada kosmetik untuk mencerahkan kulit.

\section{VITAMIN C}

Vitamin C (L-asam askorbat) merupakan antioksidan non enzimatik yang larut dalam air. Senyawa ini merupakan bagian dari sistem pertahanan tubuh terhadap senyawa oksigen reaktif dalam plasma dan sel yang pertama kali diisolasi oleh ScentGyorgyi pada tahun $1928 .{ }^{5}$ Asam askorbat berperan sebagai reduktor untuk berbagai radikal bebas. Selain itu juga meminimalkan terjadinya kerusakan yang disebabkan oleh stres oksidatif. ${ }^{6,7}$ Tiga fungsi utama vitamin C pada kulit yaitu sebagai antioksidan kuat yang melindungi kulit terhadap pengaruh negatif faktor luar seperti (polusi, matahari, iklim, AC, asap rokok, dsb); merangsang pembentukan dan peningkatan produksi kolagen kulit, yang akan menjaga kekenyalan, kelenturan, serta kehalusan kulit; dan mencerahkan kulit. ${ }^{2}$

Vitamin C sebagai antioksidan bekerja menangkap radikal bebas yang ada dalam kulit. Molekul antioksidan berfungsi sebagai sumber hidrogen labil yang akan berikatan dengan radikal bebas. Dalam proses ini, antioksidan mengikat energi yang akan digunakan untuk pembentukan radikal bebas baru sehingga reaksi oksidasi berhenti. Secara tidak langsung, vitamin C dapat meredam aktivitas dengan cara mengubah tokoferol menjadi bentuk tereduksi, dengan kata lain antioksidan "mengorbankan dirinya” untuk teroksidasi oleh radikal bebas sehingga melindungi protein atau asam amino penyusun kolagen dan elastin. $^{2}$

\section{Efek samping vitamin $\mathrm{C}$}

Vitamin C dengan dosis lebih dari 1 g/hari dapat menyebabkan diare. Hal ini terjadi karena efek iritasi langsung pada mukosa usus yang mengakibatkan peningkatan peristaltik. Dosis besar juga dapat meningkatkan bahaya terbentuknya batu ginjal, karena sebagian vitamin $\mathrm{C}$ dimetabolisme dan diekskresikan sebagai oksalat. Penggunaan vitamin $\mathrm{C}$ dosis lama dan besar dapat menyebabkan ketergantungan, sehingga vitamin $\mathrm{C}$ dapat menimbulkan rebound scurvy. Hal ini dapat dihindari dengan mengurangi penggunaan vitamin $C$ secara bertahap. ${ }^{8}$

\section{SISTEM PIGMENTASI KULIT}

Warna kulit normal manusia ditentukan oleh empat macam pigmen, yaitu: pigmen karoten yang bersifat eksogen dan memberikan warna kekuningan; pigmen melanin yang disintesis didalam kulit dan memberikan warna kecoklatan; hemoglobin teroksidasi yang memberikan warna kemerahan; dan hemoglobin tereduksi yang memberikan warna kebiruan. Dari keempat unsur tersebut pigmen melanin merupakan unsur utama warna kulit. Berdasarkan pigmentasi, melanin kulit manusia dibagi menjadi dua komponen yaitu warna kulit konstitutif yang merupakan warna kulit asli yang tidak dipengaruhi oleh faktor luar dan warna kulit fakultatif merupakan warna kulit yang telah terpapar berbagai faktor luar. ${ }^{1,9-11}$

\section{HISTOLOGI MELANOSIT}

Melanosit merupakan sel khusus yang terdapat pada epidermis, dijumpai di bawah atau di antara sel-sel stratum basalis dan pada folikel rambut. ${ }^{9,12}$ Asal embriologik dari melanosit yaitu dari sel krista neural. Melanosit memiliki bentuk badan sel bulat tempat bermulanya cabang-cabang panjang yang ireguler dalam epidermis. Cabangcabang ini berada di antara sel-sel stratum basalis dan stratum spinosum. ${ }^{9,12-15}$

\section{Sintesis melanin}

Melanin dibentuk oleh melanosit dengan enzim tirosinase yang berperan penting dalam proses pembentukannya. 
Akibat kerja enzim tirosinase, tirosin diubah menjadi 3,4 dihidroksiferil alanin (DOPA) dan kemudian menjadi DOPAquinone, yang kemudian dikonversi, setelah melalui beberapa tahap transformasi menjadi melanin. Enzim tirosinase dibentuk dalam ribosom, ditransfer dalam lumen retikulum endoplasma kasar, kemudian melanosit diakumulasi dalam vesikel yang dibentuk oleh kompleks Golgi. Terdapat empat tahap pada pembentukan granul melanin yang matang. ${ }^{12,13}$

Pada tahap pertama sebuah vesikel dikelilingi oleh membran yang menunjukkan awal proses dari aktivitas enzim tirosinase dan pembentukan substansi granul halus; pada bagian perifernya. Untaian-untaian padat elektron memiliki suatu susunan molekul tirosinase yang rapi pada sebuah matrik protein. ${ }^{12,13}$

Selanjutnya vesikel (melanosom) berbentuk oval dan pada bagian dalam memperlihatkan filamen-filamen dengan jarak sekitar $10 \mathrm{~nm}$ atau garis lintang dengan jarak sama. Melanin disimpan dalam matriks protein. kemudian peningkatan pembentukan melanin membuat struktur halus agak sulit terlihat. $^{12,13}$

Pada tahap terakhir, granul melanin matang dapat terlihat dengan mikroskop cahaya dan melanin secara sempurna mengisi vesikel. Ultrastruktur tidak ada yang terlihat. Granul yang matang berbentuk elips dengan panjang $1 \mu \mathrm{m}$ dan diameter 0,4 $\mu \mathrm{m}$. $^{12,13,16}$

Tirosinase disintesis dalam retikulum endoplasma yang kasar dan diakumulasikan dalam vesikel kompleks golgi. Vesikel yang bebas, sekarang dinamakan melanosom. ${ }^{11}$ Sintesis melanin dimulai pada melanosom tahap II, dimana melanin diakumulasikan dan membentuk melanosom tahap III. Terakhir, struktur ini hilang dengan aktivitas tirosinase dan membentuk granul melanin. Granul melanin bermigrasi ke arah juluran melanosit dan masuk ke dalam keratinosit. ${ }^{13}$

Ketika dibentuk, granul melanin bermigrasi di dalam perluasan sitoplasma melanosit dan ditransfer ke sel-sel dalam stratum germinativum dan spinosum dari epidermis. Proses transfer ini telah diobservasi secara langsung pada kultur jaringan kulit. Granul melanin pada dasarnya diinjeksikan ke dalam keratinosit. Di dalam keratinosit, granul melanin berakumulasi di sitoplasma daerah atas inti (supra-nuklear); jadi melindungi inti dari efek merusak radiasi matahari. ${ }^{16}$

Pada manusia, rasio DOPA-positif melanosit terhadap keratinosit pada statum basal ialah konstan di dalam setiap area tubuh, tetapi bervariasi dari satu regio ke regio yang lain. Sebagai contoh, terdapat sekitar 1000 melanosit $/ \mathrm{mm}^{2}$ pada kulit daerah paha dan $2000 / \mathrm{mm}^{2}$ di kulit skrotum. Jenis kelamin dan ras tidak mempengaruhi jumlah melanosit/unit area. Perbedaan pada warna kulit terutama karena perbedaan jumlah granul melanin pada keratinosit. $^{16,17}$

Makin gelapnya kulit setelah terpapar radiasi matahari (panjang gelombang: 290$320 \mathrm{~mm}$ ) ialah akibat proses tahap II. Pertama, reaksi fisik dan kimiawi menggelapkan warna melanin yang belum muncul ke luar melanosit, dan merangsangnya secara cepat untuk masuk ke keratinosit. Kedua, kecepatan sintesis melanin dalam melanosit mengalami akselerasi, sehingga semakin meningkatkan jumlah pigmen melanin. ${ }^{16}$

Secara biologik, melanin penting sebagai pelindung terhadap pengaruh buruk cahaya matahari (komponen ultraviolet). Telah diketahui bahwa individu yang berpigmen banyak lebih tahan terhadap sengatan matahari. Melanin melindungi selsel basal yang mengalami mitosis terhadap kerusakan kromosom oleh sinar ultraviolet. $^{16,17}$

\section{BAHASAN}

Vitamin C atau asam askorbat mempunyai sifat mudah teroksidasi sehingga berperan sebagai anti oksidan atau reduktor pada sintesis melanin yang banyak membutuhkan oksigen dan dapat mengubah bentuk melanin oksidasi yang berwarna gelap menjadi melanin tereduksi yang berwarna agak pucat. Vitamin $\mathrm{C}$ dalam 
megadose 1-2 g per hari per oral dapat menghambat perubahan DOPA menjadi DOPAkuinon sehingga menghambat pembentukan melanin. ${ }^{3,18}$

Kameyama et al (1990) membuktikan bahwa absorbsi per kutan asam askorbat dapat menghambat aktivitas enzim tirosinase sehingga produksi melanin terhambat dengan menurunnya o-kuinon membuat cerah kulit pada orang normal maupun orang dengan gangguan hiperpigmentasi. ${ }^{3,18} \mathrm{Da}-$ lam kasus penyakit kelainan pigmentasi, Kameyama et al menguji 34 pasien melasma dan lentigo senilis dengan menggunakan pengobatan terapi vitamin C; 19 orang di antaranya memperoleh hasil yang memuaskan. ${ }^{3}$

Asupan harian vitamin C dalam makanan maupun suplemen yaitu penggunaan oral vitamin C 50-75mg/hari untuk memenuhi kebutuhan dalam tubuh. Dalam hal kecantikan kulit dibutuhkan dosis yang tinggi, karena agar sampai ke kulit vitamin $\mathrm{C}$ harus melalui saluran cerna untuk diabsorbsi, kemudian didistribusi ke seluruh tubuh dan pembuluh darah. Untuk memperoleh efek kecantikan kulit dibutuhkan vitamin C sekitar 1000 mg; oleh karena itu telah tersedia vitamin $\mathrm{C}$ dalam bentuk larutan yang dapat langsung diaplikasikan untuk kecantikan kulit. ${ }^{19}$

Etnawati et al (2010) melakukan uji klinis penggunaan injeksi vitamin $\mathrm{C}$ dan glutation sebagai pencerah kulit di poliklinik Penyakit Kulit dan Kelamin RS Dr. Sardjito Yogyakarta dalam berbagai kombinasi dosis pemberian (Tabel 1). ${ }^{10}$ Evaluasi dilakukan secara subyektif dan obyektif dengan kromameter selama enam minggu. Sebelum dilakukan injeksi, terhadap semua subyek dilakukan pemeriksaan laboratorium untuk fungsi hati dan ginjal, dan hasil pemeriksaan menunjukkan semua subyek dalam batas normal. ${ }^{10}$

Pencerah kulit yang akan diinjeksikan yaitu vitamin C $1000 \mathrm{mg}$ dan glutation yang merupakan L-glutation reduktif sintetis dengan dosis yang bervariasi. Pada satu subyek ditambahkan kolagen $375 \mathrm{mg}$. Semua subyek sebelum dan sesudah diinjeksi dilakukan pengukuran dengan kroma- tometer atau kolorimetri pada kulit fakultatif (pipi kanan-kiri, kedua punggung tangan) dan kulit konstitutif (lengan atas volar, dan ketiak kanan-kiri). Pada minggu keempat setelah penginjeksian, semua subjek dilakukan pemeriksaan laboratorium ulang untuk fungsi hati dan ginjal. Berdasarkan hasil pemeriksaan tersebut, didapatkan hasil dalam batas normal untuk semua subyek dan semua subyek merasa kulitnya bertambah lebih bersih dibandingkan minggu sebelumnya. Pemantauan terhadap semua subyek dilakukan hingga minggu ke enam dengan hasil warna kulit mengalami kecerahan yang bermakna. ${ }^{10,11}$

Tabel 1. Dosis injeksi vitamin C yang dipakai dalam penelitian. ${ }^{10}$

\begin{tabular}{|c|c|c|c|}
\hline $\begin{array}{c}\text { Jenis } \\
\text { kelamin }\end{array}$ & $\begin{array}{c}\text { Jumlah } \\
\text { subjek }\end{array}$ & Pekerjaan & $\begin{array}{c}\text { Dosis dan } \\
\text { jenis zat } \\
\text { yang } \\
\text { disuntikkan }\end{array}$ \\
\hline $\begin{array}{c}\text { Perem- } \\
\text { puan }\end{array}$ & 2 & Perawat & $\begin{array}{c}\text { Vit C } 1 \text { g, } \\
\text { glutation } \\
600 \mathrm{mg}\end{array}$ \\
\hline $\begin{array}{l}\text { Laki- } \\
\text { laki }\end{array}$ & 1 & Perawat & $\begin{array}{l}\text { Vit C } 1 \text { g, } \\
\text { glutation } \\
200 \mathrm{mg}\end{array}$ \\
\hline $\begin{array}{c}\text { Perem- } \\
\text { puan }\end{array}$ & 1 & Karyawan & $\begin{array}{c}\text { Glutation } \\
600 \mathrm{mg}\end{array}$ \\
\hline $\begin{array}{c}\text { Laki- } \\
\text { laki }\end{array}$ & 1 & Karyawan & Vit C $1 \mathrm{~g}$ \\
\hline $\begin{array}{c}\text { Perem- } \\
\text { puan }\end{array}$ & 2 & IRT & $\begin{array}{l}\text { Vit C } 1 \text { g, } \\
\text { glutation } \\
600 \text { mg dan } \\
\text { kolagen } 375 \\
\text { mg }\end{array}$ \\
\hline
\end{tabular}

\section{SIMPULAN}

Warna kulit normal manusia ditentukan oleh empat macam pigmen, yaitu: karoten, melanin, hemoglobin teroksidasi dan hemoglobin tereduksi.

Melanosit merupakan sel khusus pada epidermis yang membentuk melanin.

Vitamin $\mathrm{C}$ berperan mengubah melanin bentuk teroksidasi menjadi melanin bentuk tereduksi yang berwarna lebih pucat, serta mencegah pembentukan melanin 
dengan menghambat pembentukan dopa menjadi dopa kuinon. Dengan demikian kulit menjadi lebih cerah baik pada kulit normal maupun yang dengan gangguan pigmentasi (hiperpigmentasi).

\section{DAFTAR PUSTAKA}

1. Djuanda A. Ilmu Penyakit Kulit dan Kelamin (Edisi Keempat). Jakarta: Penerbit Balai Penerbitan Buku FKUI, 2006; p.1, 289-92.

2. Vitamin $\mathrm{C}$ as antioxidant [homepage on the Internet]. 2002 [cited 2002 Nov 11]. Available from: URL: http//www. exrx.net/nutrition/antioksidan/vitamin c.htm.

3. Baumann L, Allemann IB. Depigmenting agents. In: Baumann L, Saghari S, Weisberg E, editors. Cosmetic Dermatology Principles and Practice (Second Edition). New York: McGrawHill Co, 2009; p. 284-5.

4. Baumann L, Allemann IB. Antioxidants. In: Baumann L, Saghari S, Weisberg E, editors. Cosmetic Dermatology Principles and Practice (Second Edition). New York: McGraw-Hill Co, 2009; p. 298.

5. Shapiro SS, Saliou C. Role of vitamins in skin care. Nutrition [homepage on the Internet]. 2001 [cited: 2012 Jan 13]. Available from: http://dexamedica.com.

6. Zakaria FR. Peranan zat-zat gizi dalam sistem kekebalan tubuh. Buletin Teknologi dan Industri Pangan. 1996;7(3):75-81.

7. Foyer C. Scorbic Acid. In: Alssher RG, Hess JL, editors. Antioxidants in Higher Plants. Boca Raton: CPC Press, 1993; p. 31-58.

8. Dewoto HR. Vitamin dan mineral. In: Gunawan SG, Setiabudy R, Nafrialdi, Elysabeth, editors. Farmakologi dan Terapi (Edisi 5). Jakarta: Departemen Farmakologi dan Terapeutik FKUI, 2007; p. 777-9.

9. Bloom W, Fawcett DW. Buku Ajar Histologi (Edisi Keduapuluhsatu).
Jakarta: Penerbit Buku Kedokteran EGC, 1994; p.536-46.

10. Etnawati K, Agoeng T, Dwi Retno, Betty ES. Pengaruh berbagai kombinasi dosis pemberian vitamin $\mathrm{C}$ dan glutation injeksi pada warna kulit evaluasi kromametrik terhadap tujuh kasus [homepage on the Internet]. Nodate [cited Jan 28, 2010]. Available from: http://www.dermatofarma.wordpress. com: 1

11. Yasik YR. Vitamin $C$ untuk kecantikan kulit [homepage on the Internet]. Nodate [cited 2008 Dec 10]. Available from: http://cntiknatural.com.

12. Fitrie AA. Histologi dari melanosit. Kumpulan Bahan Ajar Bagian Histologi. Medan, Fakultas Kedokteran Universitas Sumatera Utara, 2004.

13. Mescher AL. Junqueira's Basic Histology Text \& Atlas (Twelfth Edition). New York: Mc Graw-Hill, 2010.

14. MosGraw-Hillher DB, Fitzpatrick TB, Ortone JP, Hori Y. Normal skin colour and general consideration of pigmentary disorder. In: Freeberg I M, Eisen AZ, Wolff K, Austen KF, Goldsmith LA, Katz SI, Fitzpatrick TB, editors. Dermatology in General Dermatology Medicine (Fifth Edition). McGraw-Hill, 1999; p.936-944.

15. James JN. Introduction to the biology of the pigment system. In: Moschella SL, Hurley HJ, editors. Dermatology (Third Edition). Philadelphia: W B Saunders Co, 1992; p.1421-39.

16. Kang S, Jobe JA. Disturbances of melanin pigmentation. In: Moschella SL, Hurley HJ, editors. Dermatology (Third Edition). Philadelphia: W.B Saunders Co, 1992; p.1442-71.

17. Geneser F. Buku Teks Histologi (Edisi Kedua). Jakarta: Binarupa Aksara, 1994; p.70-5.

18. Cormack DH. Introduction to Histology. Philadelphia: J.B. Lippincott Company, 1984; 299-303e

19. RDA - Recommended Dietary Allowanca dari unsur-unsur gizi. [cited 2011 Nov 1]. Available from: http://www.any vitamins.com/rda.htm. 